\title{
ランダム成長ZnOナノロッドによるプラズモン増強ラマン散乱
}

\author{
坂野 竜則, 田中悠人, 小原 豪, 寺川光洋, 小原 實 \\ 慶應義塾大学 理工学部電子工学科 (广223-8522 神奈川県横浜市港北区日吉3-14-1)
}

\section{Raman Scattering Enhanced by Plasmonic Near-Field of Randomly Grown ZnO Nanorods Template}

\author{
Tatsunori SAKANO, Yuto TANAKA, Go OBARA, Mitsuhiro TERAKAWA, and Minoru OBARA \\ Department of Electronics and Electrical Engineering, Keio University, 3-14-1 Hiyoshi, Kohoku-ku, Yokohama, Kanagawa 223-8522
}

(Received September 14, 2010)

\begin{abstract}
This paper reviews the enhanced Raman scattering properties by use of $\mathrm{ZnO}$ nanorods template prepared by two-step, off-axis PLD method. The two-step PLD consists of the seed preparation stage and off-axis nanorod growth stage. The fabricated $\mathrm{ZnO}$ nanorods range from $100 \mathrm{~nm}$ to $400 \mathrm{~nm}$ in diameter. The Surface Enhanced Raman Scattering (SERS) properties of gold-coated ZnO nanoshells by the surface plasmons and of bare $\mathrm{ZnO}$ nanorods by the resonant Mie scattering near-field are compared. The nearfield properties are also analyzed by FDTD method.
\end{abstract}

Key Words: Zinc oxide, Nanorod, Nanowire, PLD, SERS, Plasmon, Mie scattering, FDTD

1. はじめに

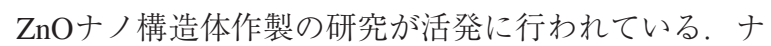
ノロッドの発光デバイスを目指した研究も活発であり, その進展の詳細な解説は文献 に譲る。本解説論文で は, $\mathrm{ZnO}$ の光スペクトル領域での屈折率の高さとナノ構 造の特徴を活かしたプラズモン増強ラマン散乱への応用 に関して著者らの研究を含めて解説する。ラマン散乱は 表面分析に非常に有効な方法であるが, ラマン散乱の断 面積は極めて小さい. この散乱光強度を増強する方法と して, SERS (表面増強ラマン散乱：Surface Enhanced Raman Scattering)に注目が集まっている。最近では, 金 $^{2)}$, 銀 ${ }^{3-5)}$, 銅 ${ }^{6}$ などの金属ナノロッドを用いて大きな SERS信号を得ている。金ナノ構造体を用いたSERS特性 の報告は多い ${ }^{7-9)}$ 。一方で, 誘電体 (コア)の表面を金属 コーティングしたナノシェル (nanoshell) ${ }^{10)}$ と呼ばれる構 造もSERS研究で注目されている.SERS特性は基板表面 ナノ構造に強く依存する。ナノ構造 $\mathrm{ZnO}$ な゙を用いれ ば，高いSERS特性が得られる。銀コーティングしたナ ノシェル構造が高いSERS特性を示すことが報告されて いる ${ }^{11)}$.

本論文では, 最初にPLD法によるZnOナノロッドの作 製・構造制御について解説し, 続いてそのプラズモン増 強ラマン散乱への適用について述べる.

\section{PLD法によるZnOナノロッドの作製・構造制御}

PLD (Pulsed Laser Deposition：パルスレーザー薄膜堆 積)において，ナノロッド構造体成長制御パラメータウ インドウは非常に狭い. パラメータは, レーザーアブ レーションパラメータ, 成長基板温度, 雲囲気ガス種・ 圧力，成長時間等である。ナノロッド成長はこれらの成 長条件に非常に敏感であり，1つの条件が少し変わるだ けでもロッド構造が成長せず，薄膜や粒子形状になりや すい，著者らは，2段階成長法を採用することで高品質

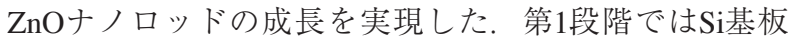
上に散布したZnO粉末をアニーリングして，ナノロッド の成長核となるシード層を作製し，第2段階ではPLD法 により $\mathrm{ZnO}$ ナノッドを成長させた。新しく軸ズレ (offaxis)配置した成長基板上にナノロッドを成長させた。

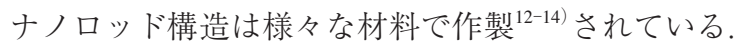
化学的自己組織化手法 ${ }^{15,16)}$ も多いが, そのナノロッドは 低温成長のため多くの欠陷を含む．PLD法では高品質ナ ノ構造体が比較的容易に成長できる，PLD法によって

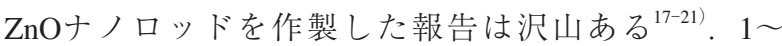
10 Torr $(1$ Torr $=133.3 \mathrm{~Pa})$ 程度の高酸素䨌囲気中でPLD法 を適用するのが大きな特徵である 22,23$)$ ，微小ポリスチレ ン球を2次元配列させ，その隙間に金を堆積させること

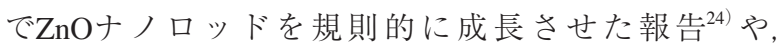
金 $^{25)}$ ，銅 ${ }^{26)}$ などの金属触媒を用いて，VLS(Vapor Liquid

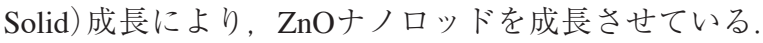


しかし，金属触媒VLS成長させるとナノロッドに微量の 金属触媒が残留することが観測されている，それ故，無 触媒プロセスでナノロッドを成長させることが，ナノ ロッド応用を指向した研究では重要である。本研究では 金属触媒無しの2ステップoff-axis PLDプロセスによっ て，高品質ナノロッドを作製する ${ }^{27)}$.

\subsection{2ステップPLDプロセス}

ここでは2ステップPLDプロセスでナノロッドを成長 させる。ナノロッド成長が始まる結晶核を作製すること が重要であるので, 高温アニーリングで微結晶を薄膜中 に形成させる。ナノロッド作製の成長基板として，エピ タキシャル成長関係がランダムな Siを選択した。洗浄し た $\mathrm{Si}$ (100) 基板上に $\mathrm{ZnO}$ (純度 : $99.99 \%$ ) 多結晶粉末(数百 $\mathrm{nm}$ 径の微粒子) を500 $\mu \mathrm{m}$ の厚さで配置し, 大気中でプレ アニーリング $\left(1150{ }^{\circ} \mathrm{C}\right) を, 2.5$ 時間行った。 この試料上 に第2段階として, PLD法により ZnOを堆積させた。ア ブレーションには $\mathrm{KrF}$ エシンレーザー(波長 $248 \mathrm{~nm}$, パルス幅 $27 \mathrm{ns,}$ 繰り返し周波数 $10 \mathrm{~Hz}$ )を用い, レー ザーフルエンス $3 \mathrm{~J} / \mathrm{cm}^{2}$ ，基板温度 $650{ }^{\circ} \mathrm{C}$ で $\mathrm{ZnO}$ を 1 時間

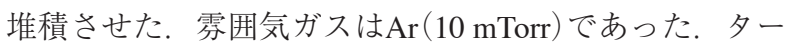
ゲットはZnO焼結体で，5 rpmで回転させながらレー ザー照射した。高いKrFレーザーフルエンス $\left(3.0 \mathrm{~J} / \mathrm{cm}^{2}\right)$ を用いると，プルーム中の粒子エネルギーが大きくなる ので，成長基板の水平方向に取り込まれず結晶核上でエ ネルギーを失い, 新たな結晶核となる。 これにより水平 方向の成長速度よりも垂直方向の成長速度を増大できる のでナノロッドの成長が達成できる。

プルーム密度が独立に制御できる方法がoff-axis PLD 法である。ターゲット表面におけるレーザー照射点を中 心とした対向軸からの距離を軸ズレの位置 $\left(d_{o f f}\right)$ と定義 する。実験では $d_{o f f}$ を変化させてナノロッドを成長させ， その寸法を制御した， $d_{\text {off }}$ に対するナノロッドの平均直 径と長さをFig. 1に示す。直径が大きくなれば，ロッド の長さが短くなることが分かる，基板位置がプルーム中 心から離れるにつれて, 成長ナノロッドの直径は細く なっていく. $10 \mathrm{~mm}$ の時のナノロッドの平均直径は $250 \mathrm{~nm}$, 長さは約 $3.5 \mu \mathrm{m}$ である. $30 \mathrm{~mm}$ らした時の ロッドの平均直径は $100 \mathrm{~nm}$, 長さ約 $5 \mu \mathrm{m}$ である. 特に

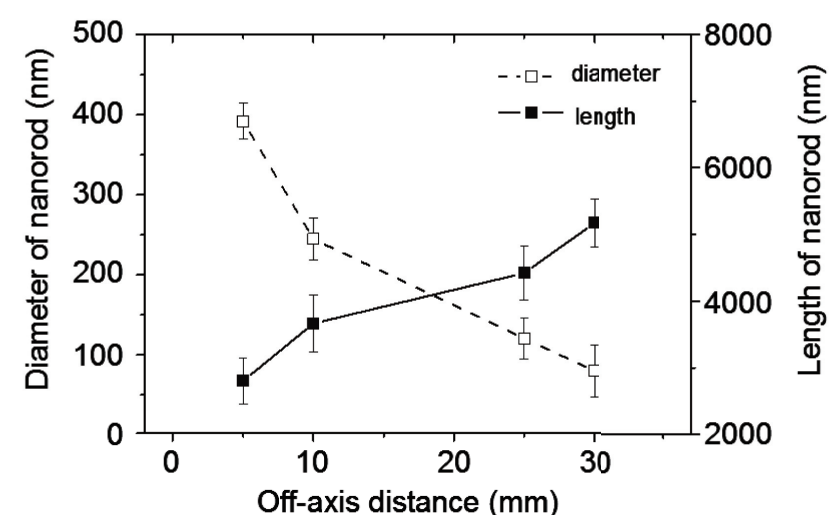

Fig. 1 Dependence of the average diameter (white square) and the average length (black square) of nanorods on the off-axis distance.
$30 \mathrm{~mm}$ で最も細径のものは直径10-50 nm程度である。本 手法で極めて細径のロッドが作製できた。ナノロッドの アスペクト比は6-100と広い範囲であった。

\section{2 成長軸制御}

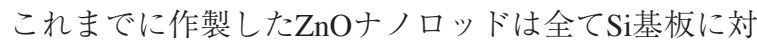
してランダム方向成長した。結晶成長核の微結晶の方向 を制御できれば, ナノロッド成長方向制御が出来る. シード層にエピタキシャル関係を維持するために，シー ド層をサファイア基板上へPLD法で作製し，その後のア ニーリングでシード層を結晶化させる．PLDシード層上 に成長したZnOナノロッドのSEM像をFig. 2に示す。ラ ンダム成長しているロッドも観察できるが，基板に垂直 に成長しているZnOナノロッドが支配的である。よって PLDシード層を用いると $\mathrm{ZnO}$ のエピタキシャル関係の方 向にZnOナノロッドが成長できることが実証できた。 PLDシード層上でも $d_{o f f}$ によって垂直成長を維持して, 寸 法制御が実証できた。ナノロッドの光学的特性はCL (cathode luminescence)測定で評価した。波長370 nm付近 のピークは $\mathrm{ZnO}$ のバンドギャップ由来 ${ }^{28}$ で, $505 \mathrm{~nm}$ 付近 のブロード・スペクトルは酸素欠陥由来である ${ }^{29)}$. $650 \mathrm{~nm}$ 付近のブロード・スペクトルは酸素等が格子間 に入り込むための点欠陥由来である ${ }^{30)}$ 。ここで作製した

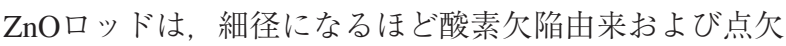
陥由来のスペクトルがみられず、高品質になる.

\section{ZnOナノロッドテンプレートの プラズモン増強ラマン散乱}

3.1 金コーティング $\mathrm{ZnOナノロッドテンプレート}$

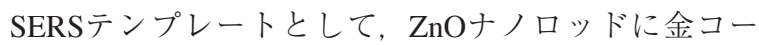
ティングし, 表面プラズモン波を発生させ, 増強ラマン 散乱を計測した。ラマン試料としてRhodamine 6G(R6G) を修飾した，PLD法ではロッド寸法を制御できるので, 2つの寸法のナノロッドを準備しラマン散乱測定するこ とによって，プラズモン共鳴波長の依存性を明らかにし た

ナノロッド寸法は平均直径 $150 \mathrm{~nm}$, 長さは約 $4 \mu \mathrm{m}$ で

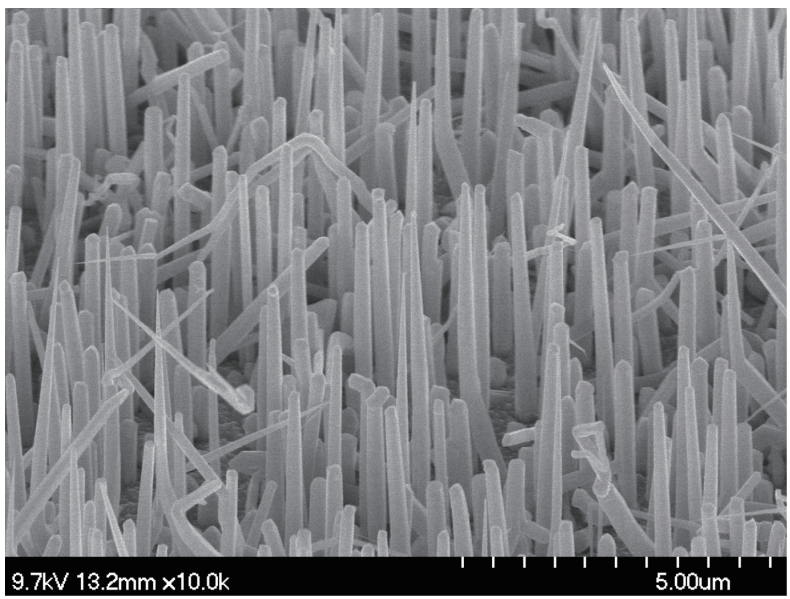

Fig. 2 SEM image of $\mathrm{ZnO}$ nanorod arrays grown on PLD seed layer. 
ある。このナノロッドにイオンスパッタで金コーティン グした，膜厚は約 $10 \mathrm{~nm}$ であった。このナノシェル構造

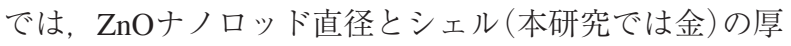
さの構造にSERS効果が依存し, SERS特性の最適構造が 存在する ${ }^{10)}$. 金コーティングした $\mathrm{ZnO}$ ナノロッドの SERS特性を評価するために, R6Gをこの試料に修飾し た。比較のために, 直接 $\mathrm{Si}$ 基板上に $5 \mu \mathrm{M}$ のR6Gを滴下し た試料と， $\mathrm{Si}$ 基板にイオンスパッタで作製した金薄膜試 料にも同じ量のR6Gを修飾させた。 R6G濃度を $1 \mu \mathrm{M}$ 滴下 した試料についてもラマン散乱測定を行った。

ラマン散乱は励起波長 $532 \mathrm{~nm}$ のレーザー光源を用い $\left(532 \mathrm{~nm}\right.$ において金の吸収係数は $\left.5.7 \times 10^{7} \mathrm{~cm}^{-132)}\right)$, 光出 力 $3 \mathrm{~mW}$, スポット径 $3 \mu \mathrm{m}\left(4.2 \times 10^{4} \mathrm{~W} / \mathrm{cm}^{2}\right)$ の条件で測 定を行った。直径 $150 \mathrm{~nm}$ の $\mathrm{ZnO} O$ ナロッドテンプレート に金を10 nm厚コーティングしたZnOナノロッドによる R6G濃度5 $\mu \mathrm{M}$ のラマン散乱測定結果をFig. 3に示す. Si 基板および金薄膜からは, $970 \mathrm{~cm}^{-1}$ 付近にわずかなス トークススペクトルが見られるのみである。このスペク トルは基板のSiに由来するので ${ }^{33)}$ ， R6Gのラマンスペク トルは全く観測されない. 金コーティングした $\mathrm{ZnO}$ ナノ ロッドでは $\mathrm{Si}$ のスペクトルの他にR6G由来のストークス スペクトルが観測されるので34，高いSERS特性が確認 された。また、R6G濃度を $1 \mu \mathrm{M}$ 滴下した試料について も、5 $\mathrm{MM}$ の結果程強いラマン信号ではないものの、全 てのピークが観察された。ZnOに銀コーティングしたナ

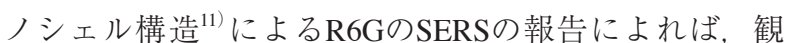

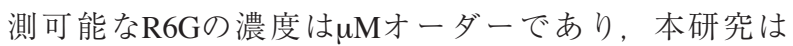
$\mathrm{ZnO}$ に銀コーティングしたナノシェル構造と同レベルの SERS特性が得られたと言える。このSERS特性は, R6G の共鳴ラマン散乱の増強 ${ }^{35)}$, ならびに $\mathrm{ZnO} O$ ナロッドの ナノシェル構造のプラズモン増強近接場光由来の表面増 強ラマン散乱による ${ }^{36)}$.

\subsection{SERSのロッド寸法依存性}

表面プラズモンによる増強近接場光由来のSERS特性 のロッド寸法依存性を評価する，各試料のナノロッド寸

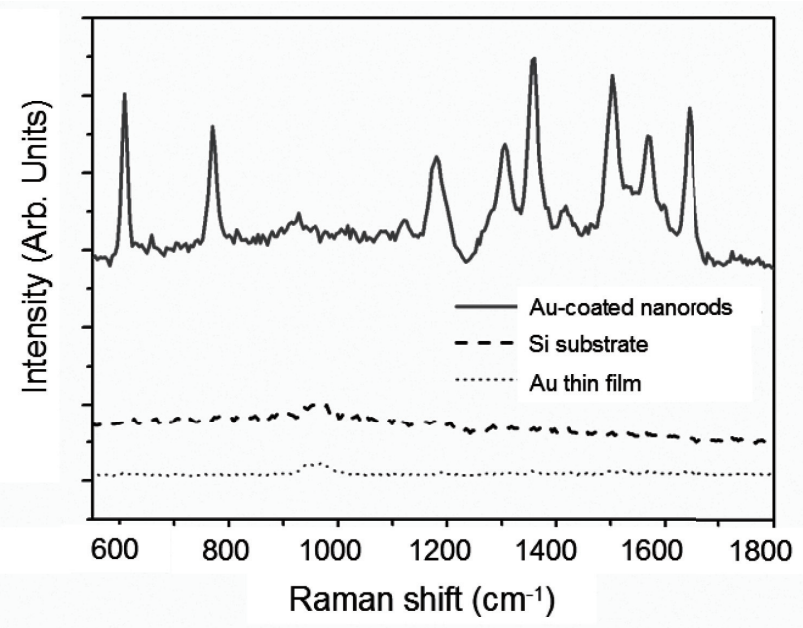

Fig. 3 Raman spectra of gold-coated $\mathrm{ZnO}$ nanorod arrays with a diameter of $150 \mathrm{~nm}$ using a $5 \mu \mathrm{M}$ of R6G. The excitation wavelength is $532 \mathrm{~nm}$.
法は細いロッドが平均直径 $150 \mathrm{~nm}$, 太いロッドは

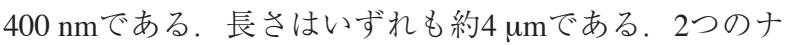
ノロッドとも金コーティングした。 ラマン散乱測定結果 をFig. 4に示す。ここでは濃度1 $\mu \mathrm{M}$ のR6Gを用いた。直 径 $400 \mathrm{~nm}$ の $\mathrm{ZnO} O$ ナッドは, 直径 $150 \mathrm{~nm}$ の試料より も，さらに高いSERS特性を示した。これは金コーティ ングしたナノロッドのナノシェル構造によるプラズモン 共鳴スペクトルで説明される。ここで重要なパラメータ であるのがロッドのアスペクト比である。ナノロッドの アスペクト比は直径 $150 \mathrm{~nm}$ で27, 直径 $400 \mathrm{~nm}$ で10であ る。銀ナノロッドにおいても，プラズモン共鳴がそのア スペクト比によって大きく変化する ${ }^{37)}$.

本研究で用いたナノロッドは複雑な配置であるため, 厳密な理論計算は困難を極めるが, 1つの指標としてナ ノロッドを真空中に配置した1本の金円柱と仮定して, その散乱効率をレイリー散乱に基づいて計算した。 円柱 に対する散乱の式 ${ }^{38)}$ を適用する。遠方場での散乱効率 $Q_{\text {sca }}$ は次式で表される。

$$
\begin{gathered}
Q_{\text {sca }}=\frac{\pi^{2}}{4}\left|\frac{n^{2}-1}{n^{2}+1}\right| q^{3} \\
q=\frac{2 \pi a n_{\mathrm{m}}}{\lambda}
\end{gathered}
$$

ここで, $n=\frac{n_{\mathrm{p}}}{n_{\mathrm{m}}}$ であり, $n_{\mathrm{p}}$ は金の複素屈折率, $n_{\mathrm{m}}$ は媒質 の屈折率である. $a$ は円柱(ロッド)の半径， $\lambda$ は入射波 長である。構造が散乱に与える影響を考慮するため係数 $2 a L$ ( $L$ : 円柱の長さ)を(1)から得られた值にかけた。こ のようにして波長 $532 \mathrm{~nm}$ における散乱断面積を算出する と, 直径 $150 \mathrm{~nm}$ で $0.09 \times 10^{-10} \mathrm{~m}^{2}, 400 \mathrm{~nm}$ で $4.6 \times 10^{-10} \mathrm{~m}^{2}$ とな り, 直径400 nmの方が50倍大きな值を取ることが分

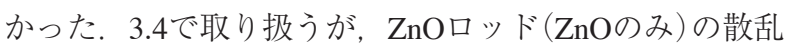
断面積を計算すると直径 $150 \mathrm{~nm}$ では $6.24 \times 10^{-13} \mathrm{~m}^{2}$, 直 径400 nmでは3.15 × $10^{-11} \mathrm{~m}^{2}$ (概ね51倍大きい) となる.

Fig. 5は，R6G濃度100，10，1 nMの400 nm直径に金

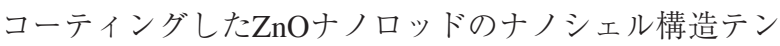

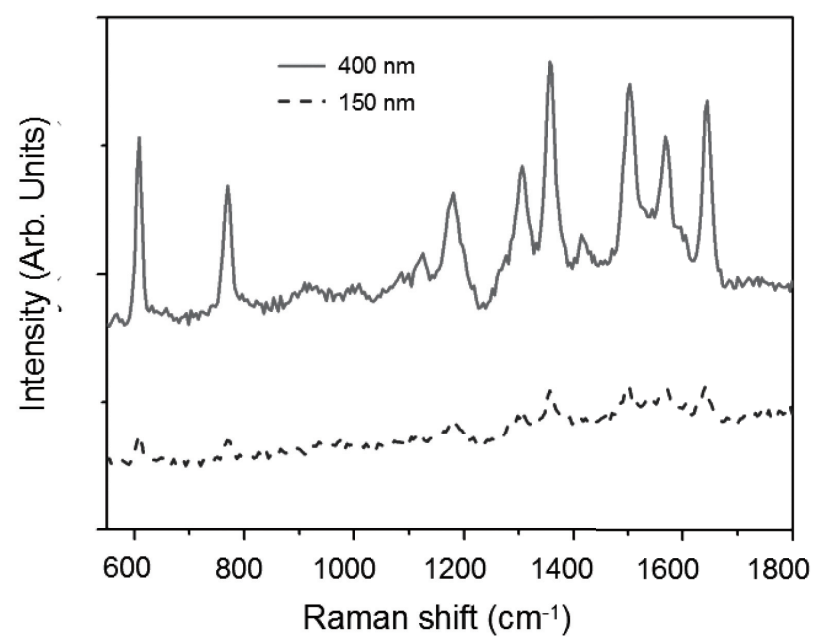

Fig. 4 Raman spectra of $\mathrm{ZnO}$ nanorod arrays with diameters of $150 \mathrm{~nm}$ and $400 \mathrm{~nm}$. The concentration of $\mathrm{R} 6 \mathrm{G}$ is $1 \mu \mathrm{M}$. 


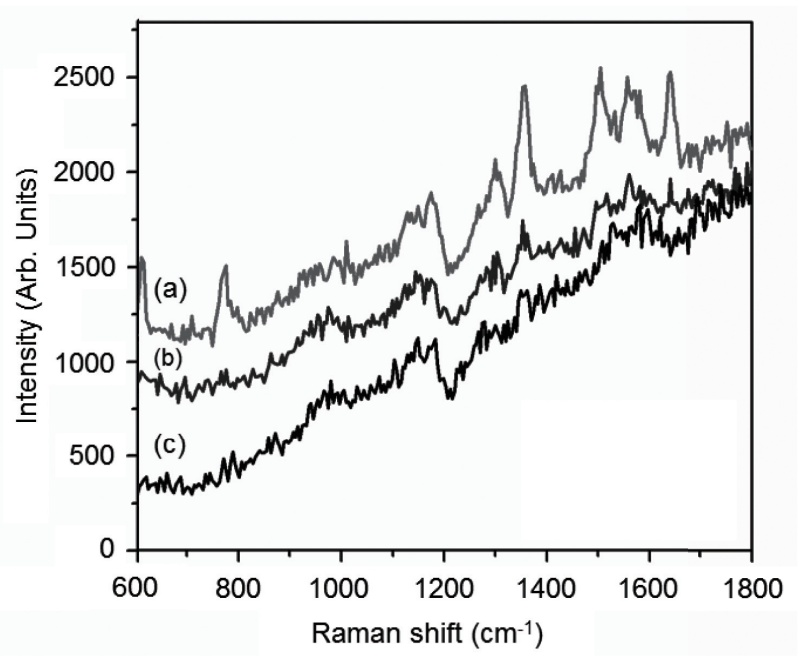

Fig. 5 Comparison of SERS spectra of $400 \mathrm{~nm}$ diameter gold-coated $\mathrm{ZnO}$ nanorods for $\mathrm{R} 6 \mathrm{G}$ of (a) $100 \mathrm{nM}$, (b) $10 \mathrm{nM}$, and (c) $1 \mathrm{nM}$.

プレートでのR6GのSERSスペクトルである，R6Gが $100 \mathrm{nM}$ 場合はラマン信号が明確に観測することがで

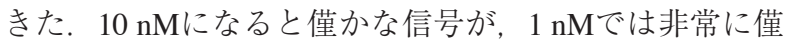
かなR6G由来のラマン信号が775 $\mathrm{cm}^{-1} や 1314 \mathrm{~cm}^{-1}$ の波数 において検出することができた。 よってこのテンプレー トは1 nMレベルが検出限界であることが分かった.

3.3 FDTD法によるプラズモニック近接場光分布の解析 金コーティングしたZnOナノシェル構造のSERS特性 を評価するために，有限差分時間領域 (FDTD: FiniteDifference Time-Domain) 法による近接場光強度分布の数

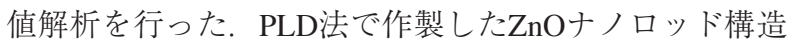
をモデル化するには複雑であるので, 簡単なモデルでシ ミュレーションを行う。本モデルでは5 $32 \mathrm{~nm}$ の平面波 を金コーティングした $\mathrm{nO} O$ ナシェル構造に照射する。 直径が $150 \mathrm{~nm}$ と $400 \mathrm{~nm}$ のナノロッドに10 nmの金コー ティングしたナノシェル構造を配置して光強度分布を解

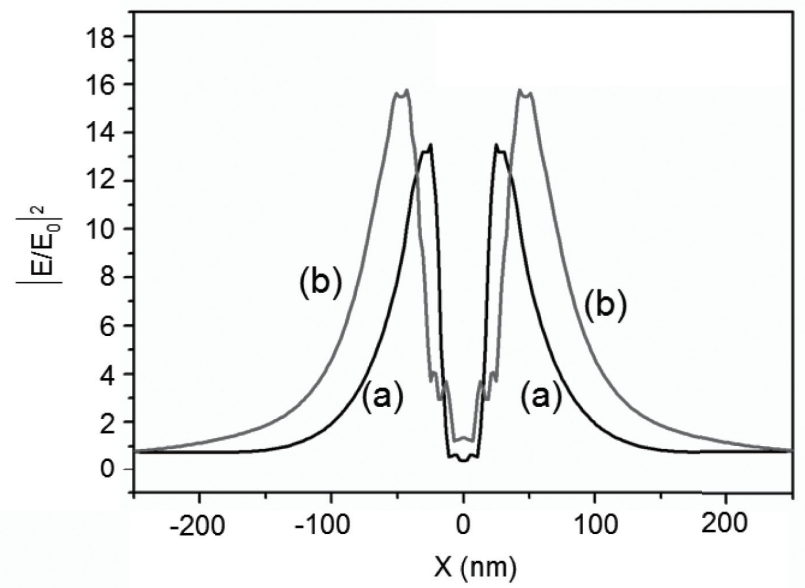

Fig. 6 Enhanced optical intensity profile (cross-sectional view) of gold-coated $\mathrm{ZnO}$ nanorods with diameters of (a) $150 \mathrm{~nm}$ and (b) $400 \mathrm{~nm}$ on the Au surface for the system consisting of the gold-coated $\mathrm{ZnO}$ nanoshells and Au substrate. Nanoshell is touching the substrate. $\mathrm{x}=0$ indicates the touching point of nanoshell and substrate.
析した． $532 \mathrm{~nm}$ 光がナノロッドに入射すると，プラズ モン近接場がロッド表面近傍に発生することが明らかに なった，PLD法で作製したZnOナノロッドはランダム方 向に成長しているためにナノシェル同士が接近する場所 が多く形成される。ナノシェルと金基板表面が直接接触 した場合の金基板表面に拈ける近接場強度分布をFig. 6 に示す。解析結果から, $400 \mathrm{~nm}$ 直径の方が $150 \mathrm{~nm}$ 直径 のロッドょりもSERS増強度が大きいことを説明でき た.

\section{4 高屈折率 $\mathrm{ZnO}$ ナノロッドテンプレート (Mie散乱 過程)}

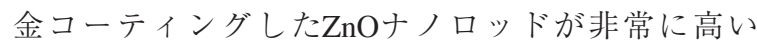
SERS増強度を持つことを示し, 直径 $400 \mathrm{~nm}$ 寸法のナノ ロッドが150 nmのロッドよりもSERS増強度が大きいこ とを示した。これは, $400 \mathrm{~nm}$ 構造のナノシェルのプラ ズモンポラリトン共鳴波長が5 $32 \mathrm{~nm}$ に近いことがSERS 増強度を高めた．SERSは励起光電界 $E$ の4乗に比例する

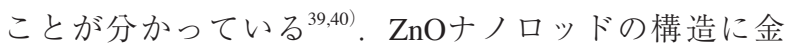
コーティングすることで表面プラズモンを利用したナノ シェルのSERSテンプレートとして応用できた。
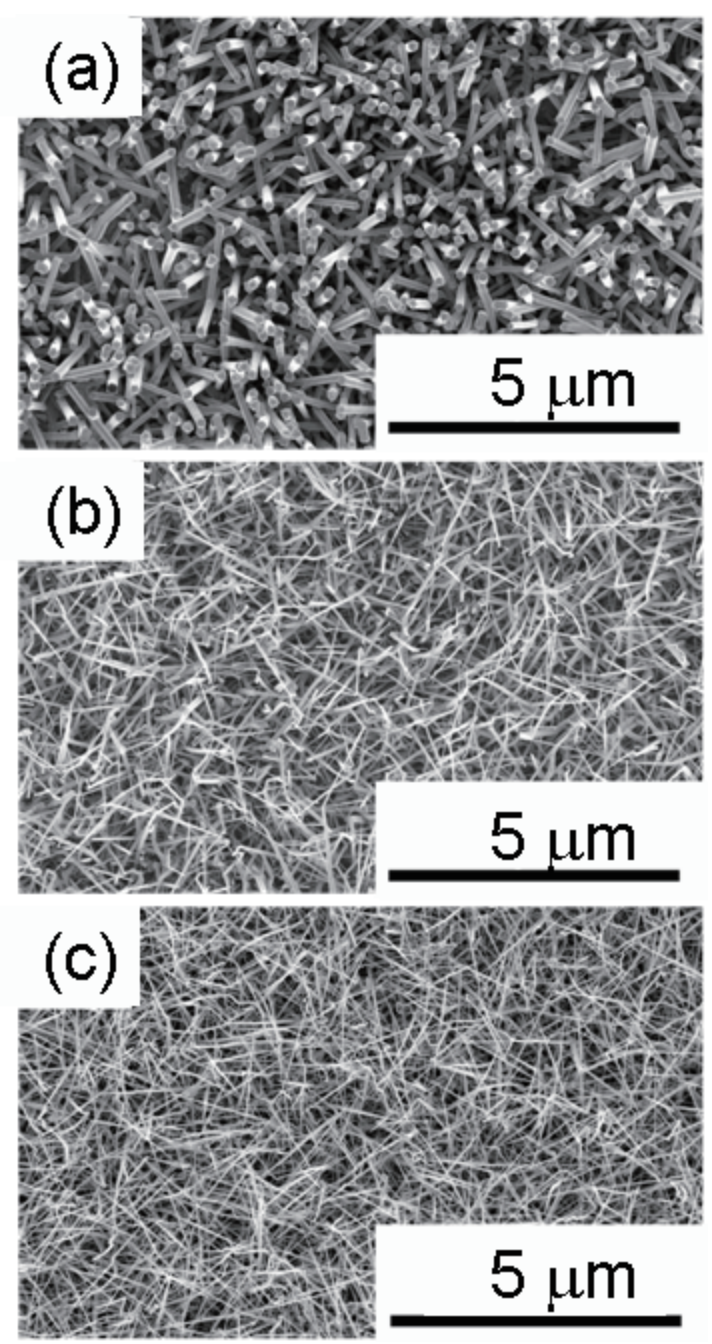

Fig. 7 FE-SEM images of $\mathrm{ZnO}$ nanorods with diameters of (a) $400 \mathrm{~nm}$, (b) $150 \mathrm{~nm}$, and (c) $100 \mathrm{~nm}$ grown on the Si substrate by the two-step, off-axis PLD. 


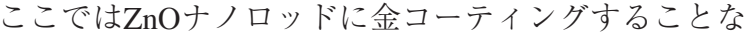
く, $\mathrm{ZnO}$ 結晶の特徵である光波長領域で高屈折率 $(\mathrm{n}=2.02, \lambda=532 \mathrm{~nm})$ を利用したラマン散乱特性につい て論ずる

$\mathrm{Si}$ 基板上に寸法の異なるナノロッドを, off-axis PLD 法で60 min, プルーム中心からのずれd $d_{\text {off }}$ それぞれ， $5 \mathrm{~mm}, 15 \mathrm{~mm}, 30 \mathrm{~mm}$ で粉末シード層上へ $\mathrm{ZnO}$ 末ノロッ ドを成長させた．3つのナノロッドのSEM画像をFig. 7に 示す。ナノロッド寸法はそれぞれ平均直径 $400 \mathrm{~nm}$, $150 \mathrm{~nm}, 100 \mathrm{~nm}$ であった。作製したナノロッドテンプ レートでラマン散乱測定を行った。

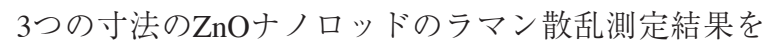
Fig. 8に示す. Fig. 8 には10 nmの膜厚で金コーティング したZnOナノロッドのラマン散乱測定結果も示す。ナノ ロッドの直径は金コーティングしたナノロッドが $(\mathrm{a})$ $400 \mathrm{~nm}, \quad(\mathrm{~b}) 150 \mathrm{~nm}, \quad(\mathrm{c}) 100 \mathrm{~nm}$ である.金コーティン グしない $\mathrm{ZnO}$ ナロッドの直径は (d) $400 \mathrm{~nm},(\mathrm{e})$ $150 \mathrm{~nm}$, (f) $100 \mathrm{~nm}$ である. Fig. 8 から, 直径 $400 \mathrm{~nm}$ の $\mathrm{ZnO}$ ナノロッドは, 金コーティングした直径 $100 \mathrm{~nm}$ の試 料と同程度の増強度を示した。また直径 $150 \mathrm{~nm}$, $100 \mathrm{~nm}$ の ZnOナノロッドではラマン散乱信号を検出でき ないことが分かった。これはR6G濃度の1 $\mu \mathrm{M}$ が検出限 界以下であることに起因する。

3.2 に記載したレイリー散乱理論に基づく計算は, 波 長に比べて比較的大きな直径のロッドにおけるサイズ依 存の電磁界共鳴現象を含んでいない, そのため, ロッド 近傍のより正確な近接場光分布 (Mie散乱近接場)の解析 を行うため, FDTD法を用いた電磁界シミュレーション を行った. Fig.9 (a)に, $400 \mathrm{~nm}$ のナノロッドと $\mathrm{ZnO}$ 基板 の間隙が $5 \mathrm{~nm}$ の配置の近接場光の強度分布の解析結果 を示す. Fig. 9 (b)に, 光強度の増強度の最大值を示し た。入射光強度の増強度は7.7倍であることが分かり， これは金コーティングした直径 $100 \mathrm{~nm}$ の試料が持つ光 強度の増強度である8.0倍と同程度の值であり, Fig. 8の

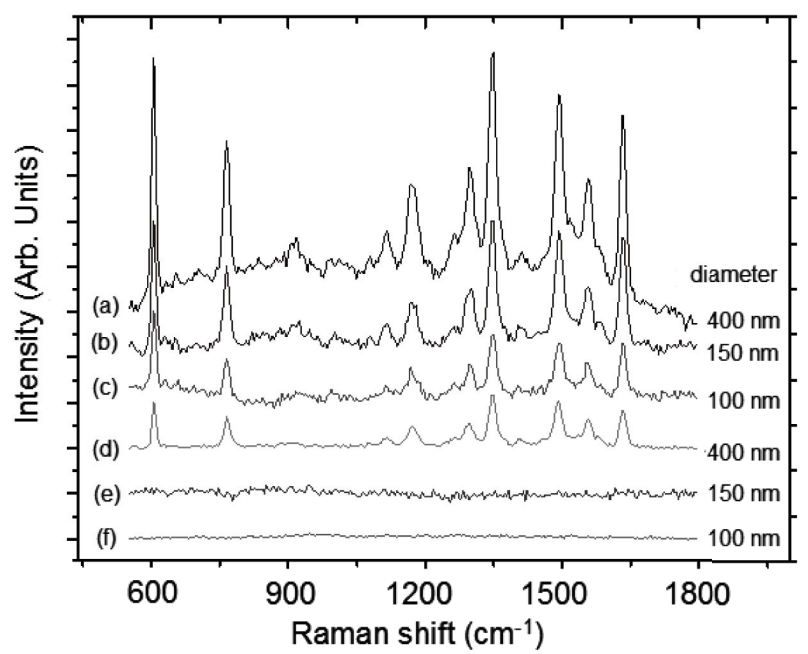

Fig. 8 Raman spectra of as-grown, bare $\mathrm{ZnO}$ nanorods (diameters of (f) $100 \mathrm{~nm}$, (e) $150 \mathrm{~nm}$, and (d) 400 $\mathrm{nm}$ ) and $10 \mathrm{~nm}$ thick Au-coated $\mathrm{ZnO}$ nanorods (diameters of (c) $100 \mathrm{~nm}$, (b) $150 \mathrm{~nm}$, and (a) 400 $\mathrm{nm})$ with R6G of $1 \mu \mathrm{M}$.
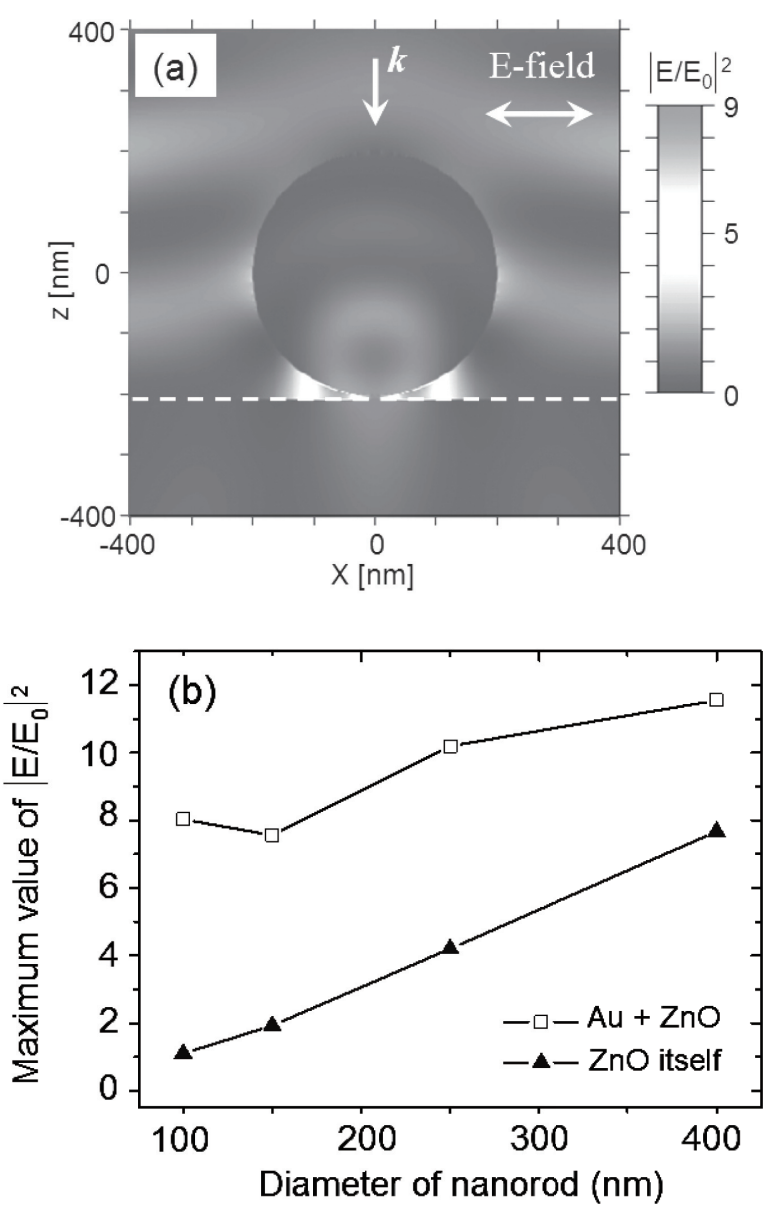

Fig. 9 (a) Calculated distribution of the optical intensity around $\mathrm{ZnO}$ with a diameter of $400 \mathrm{~nm}$ on the $\mathrm{ZnO}$ substrate. Gap distance is $5 \mathrm{~nm}$. The black and white bar shows the magnitude of the enhanced field intensity. The incident field intensity is assumed to be 1.0. (b) Size dependence of the maximum value of the optical intensity enhancement. The white square shows the maximum values for gold-coated $\mathrm{ZnO}$ nanorods, while the black triangle shows the maximum values for the bare $\mathrm{ZnO}$ nanorods.

ラマン散乱測定結果と一致する。高屈折率ナノ構造体 は，構造体寸法が光波長と同程度であると，入射光を高 効率でMie共鳴散乱するので，その増強近接場光をラマ ン散乱増強に利用できる。

これは $\mathrm{ZnO}$ 自体が持つ可視光領域での高屈折率 $(n=2.02, \lambda=532 \mathrm{~nm})$ を活かした応用であり, 高屈折率

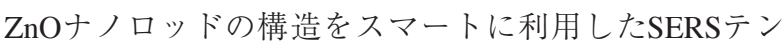
プレートへの適用事例を示した。 $\mathrm{ZnO}$ と同様に高屈折率 を有する $\mathrm{TiO}_{2}(n=2.66)$ ナノ構造体の応用展開も期待さ れる

\section{4. まとめ}

ナノロッド成長法を利用して $\mathrm{ZnO}$ ナノロッドに金コー ティングして表面プラズモンを誘起しSERSテンプレー トとして利用できるかを評価した。金コーティングした $\mathrm{ZnO}$ ナノッドで濃度 $1 \mathrm{nM}$ という非常に低濃度のR6Gを 
検出できることが分かった，直径の異なる2つの金コー ティングしたナノロッド基板のSERS測定においては, 直径 $150 \mathrm{~nm}$ よも $400 \mathrm{~nm}$ の方がより高いSERS増強度を 示すことが分かった。この理由は, 直径400 nmのナノ ロッドの方が, 励起波長 $532 \mathrm{~nm}$ の光に対してプラズモ ン共鳴に近い条件を満たしているためであった。 $\mathrm{ZnO}$ ノロッド自体 (金コーティングなし)を増強ラマン散乱近 接場 (SERSではない) 用基板として用いても, 高屈折率 $\mathrm{ZnO}$ 特性に由来する高強度Mie散乱近接場光発生が確認 できた。この散乱近接場光により高いSERS増強度が実 証できた。

ランダム成長 $\mathrm{ZnO}$ ナノロッドは，可視光のMie共鳴散 乱を高効率で誘導するので, ランダムレージング (Random Lasing $)^{42-45)}$ ，アンダーソン 局在(Anderson Localization $)^{46,47)}$ などの基板としても利用できる。さら に，成長軸と配置を制御したZnOナノロッドは，フォト ニッククリスタルへの応用展開が期待できる.

\section{謝 辞}

本研究の一部は, 科学研究費補助金 (挑戦的萌芽研 究：22656019) とグローバルCOE (慶應義塾大学 (情報電 気電子分野)アクセス空間支援基盤技術の高度国際連携) の助成によって実施されたので深謝致します。

\section{参考文献}

1) M. Willander, O.Nur, Q. X. Zhao, L. L.Yang, M. Lorenz, et al.: Nanotechnology 20 (2009) 332001.

2) B. Nikoobakht, J. Wang, and M. A. El-sayed: Chem. Phys. Lett. 366 (2002) 17.

3) S. B. Chaney, S. Shanmukh, R. A. Dluhy, and Y. P. Zhao: Appl. Phys. Lett. 87 (2005) 31908.

4) Y. P. Zhao, S. B. Chaney, S. Shanmukh, and R. A. Dluhy: J. Phys. Chem. B 110 (2006) 3153

5) Y. Yang, L. Xiong, J. Shi, and M. Nogami: Nanotechnology 17 (2006) 2670.

6) J. L. Yao, G. P. Pan, K. H. Xue, D. Y. Wu, B. Ren, D. M. Sun, J. Tang, X. Xu, and Z. Q. Tian: Pure Appl. Chem. 72 (2000) 221.

7) B. Nikoobakht and M. A. El-Sayed: J. Phys. Chem. A 107 (2003) 3372.

8) F. Toderas, M. Baia, L. Baia, and S. Astilean: Nanotechnology 18 (2007). 255702.

9) J. W. Hu, J. F. Li, B. Ren, D. Y. Wu, S. G. Sun, and Z. Q. Tian: J. Phys. Chem. C 111 (2007) 1105.

10) J. B. Jackson, S. L. Westcott, L. R. Hirsch, J. L. West, and N. J. Halas: Appl. Phys. Lett. 82 (2003) 257.

11) S. M. Prokes, O. J. Glembocki, R. W. Rendell, and M. G. Ancona: Appl. Phys. Lett. 90 (2007) 093105.

12) J. Hu, Q. Chen, Z. Xie, G. Han, R. Wang, B. Ren, Y. Zhang, Z. Yang, and Z. Tian: Adv. Funct. Mater. 14 (2004) 183.

13) L. Miao, S. Tanemura, S. Toh, K. Kaneko, and M. Tanemura: Appl. Surf. Sci. 238 (2004) 175.
14) D. Zschech, D. H. Kim, A. P. Milenin, R. Scholz, R. Hillebrand, C. J. Hawker, T. P. Russell, M. Steinhart, and U. Gosele: Nano Lett. 7 (2007) 1516

15) Y. W. Zhu, H. Z. Zhang, X. C. Sun, S. Q. Feng, J. Xu, Q. Zhao, B. Xiang, R. M. Wang, and D. P. Yu: Appl. Phys. Lett. 83 (2003) 144.

16) R. Yang and Z. L. Wang: Solid State Commun. 134 (2005) 741.

17) T. Okada, K. Kawashima, and Y. Nakata: Thin Solid Films 506 (2006) 274.

18) M. Kawakami, A.B. Hartanto, Y. Nakata, and T. Okada: Jpn. J. Appl. Phys. 42 (2003) L33.

19) S. H. Park, S. H. Kim, and S. W. Han: Nanotechnology 18 (2007) 055608.

20) A. B. Hartanto, X. Ning, Y. Nakata, and T. Okada: Appl. Phys. A 78 (2004) 299.

21) T. Okada, K. Kawashima, and M. Ueda: Appl. Phys. A, 81 (2005) 907.

22) Q. Wan, Q. H. Li, Y. J. Chen, and T. H. Wang: Appl. Phys. Lett. 84 (2004) 3654.

23) T. Okada, K. Kawashima, Y. Nakata, and X. Ning: Jpn. J. Appl. Phys. 44 (2005) 688.

24) X. Wang, C. J. Summers, and Z. L. Wang: Nano Lett. 4 (2004) 423.

25) J. Park, H. Choi, K. Siebein, and R. K. Singh: J. Cryst. Growth 258 (2003) 342.

26) S. Y. Li, C. Y. Lee, and T. Y. Tseng: J. Cryst. Growth 247 (2003) 357.

27) R. Nishimura, T. Sakano, T. Okato, T. Saiki, and M. Obara: Jpn. J. Appl. Phys. 47 (2008) 4799.

28) J. M. Lin, H. Y. Lin, C. L. Cheng, and Y. F. Chen: Nanotechnology 17 (2006) 4391

29) Z. W. Liu, C. K. Ong, T. Yu, and Z. X. Shen: Appl. Phys. Lett. 88 (2006) 053110.

30) J. W. P. Hsu, D. R. Tallant, R. L. Simpson, N. A. Missert, and R. G. Copeland: Appl. Phys. Lett. 88 (2006) 252103.

31) T. Sakano, Y. Tanaka, R. Nishimura, N. N. Nedyalkov, P. A Atanasov, T. Saiki and M. Obara: J. Physics D 41 (2008) 235304.

32) D. J. Yang, Q. Zhang, G. Chen, S. F. Yoon, J. Ahn, S. G. Wang, Q. Zhou, Q. Wang, and J. Q. Li: Phys. Rev. B 66 (2002) 165440.

33) A. C. Ferrari, S. E. Rodil, and J. Robertson: Diamond Relat. Mater. 12 (2003) 905.

34) H. Watanabe, N. Hayazawa, Y. Inoue, and S. Kawata: J. Phys. Chem. B 109 (2005) 5012.

35) N. Chandrasekharan, P. V. Kamat, J. Hu, and G. Jones: J. Phys Chem. B 104 (2000) 11103.

36) S. Link, M. B. Mohamed, and M. A. El-Sayed: J. Phys. Chem. B 103 (1999) 3073.

37) S. Eustis and M. A. El-Sayed: J. Appl. Phys. 100 (2006) 044324.

38) B. S. Luk'yanchuk and V. Ternovsky: Phys. Rev. B 73 (2006) 235432.

39) M. Inoue and K. Ohtaka: J. Phys. Soc. Jpn. 52 (1983) 3853.

40) T. Itoh, K. Yoshida, V. Biju, Y. Kikkawa, M. Ishikawa, and Y. Ozaki: Phys. Rev. B 76 (2007) 085405.

41) Y. Tanaka, G. Obara, A. Zenidaka, M. Terakawa, and M. Obara Appl. Phys. Lett. 96 (2010) 261103.

42) H. Cao, Y. Zhao, S. T. Ho, E. W. Seelig, Z. H. Wang, and R. P. H Chang: Phys. Rev. Lett. 82 (1999) 2278.

43) H-C Hsu, C-Y Wu, and W-F Hsieh: J. Appl. Phys. Lett. 97 (2005) 064315.

44) S. Takeda and M. Obara: Appl. Phys. B 98 (2009) 267.

45) S. Takeda and M. Obara: Appl. Phys. B 94 (2009) 443.

46) P. W. Anderson: Philos. Mag B 52 (1985) 505.

47) S. John: Physics Today (May 1991) 32 